\title{
Thermal Efficiency Evaluation of a Solar Thermal Steam Generating System Using Thermosiphon Technique with Parabolic Trough Collector
}

\author{
Abiem Louis Tersoo ${ }^{1,}$, , Akoshile Clement Olufemi ${ }^{2}$ \\ ${ }^{1}$ Department of Physics, Federal University of Agriculture, Makurdi, Nigeria \\ ${ }^{2}$ Department of Physics, University of Ilorin, Ilorin, Nigeria \\ Email address: \\ abiem.lot@uam.edu.ng (A. L. Tersoo),bsrnclem@yahoo.co.uk (A. C. Olufemi) \\ ${ }^{*}$ Corresponding author
}

\section{To cite this article:}

Abiem Louis Tersoo, Akoshile Clement Olufemi. Thermal Efficiency Evaluation of a Solar Thermal Steam Generating System Using Thermosiphon Technique with Parabolic Trough Collector. Journal of Energy and Natural Resources. Vol. 9, No. 1, 2020, pp. 28-34. doi: 10.11648/j.jenr.20200901.14

Received: December 24, 2019; Accepted: January 13, 2020; Published: February 20, 2020

\begin{abstract}
Parabolic trough solar collectors are the most widely used concentrators for solar thermal applications in the world. This is because very high temperatures of $150^{\circ} \mathrm{C}$ to $350^{\circ} \mathrm{C}$ can be attained with its use without any noticeable degradation in the performance of the collector. In this work, a parabolic trough collector (PTC) was designed using simple parabolic equations and constructed with locally sourced materials. The developed PTC was used to converge direct solar radiation to a heat receiver (a copper pipe enclosed in an evacuated glass tube) placed at the focal line of the trough to heat up the water in the pipe to steam. Natural circulation (thermosiphon) was employed to drive the water from the heat source to the heat sink (tank) with the difference in density as the driving force of the system. Temperature sensors were installed at different points of the solar thermal system to experimentally investigate temperature distribution within the system, hence thermal performance. A pressure sensor was also installed in the tank to measure the pressure within the system. The results obtained shows that the solar thermal system generated low-mid temperature steam of up to $105^{\circ} \mathrm{C}$ at a pressure of approximately 120 $\mathrm{kPa}$ on a day when the global solar radiation intensity attained a value of $1109.5 \mathrm{~W} / \mathrm{m}^{2}$. A thermosiphon mass flow rate of up to $0.042 \mathrm{~kg} / \mathrm{s}$ was also recorded through a constant orifice of $12 \mathrm{~mm}$ diameter. The instantaneous efficiency of the receiver reached $46.48 \%$.
\end{abstract}

Keywords: Thermosiphon, Solar Thermal, Steam Generating System, Thermal Efficiency

\section{Introduction}

Energy is a key factor for national development; as man's activities, whether domestic or industrial depend largely on its availability and accessibility. All energy systems aims at providing services that are important to man. These services range from domestic (heating, cooling and cooking) to industrial (manufacturing and construction). Energy is obtained from several sources; coal, oil and gas, renewables like solar, wind, geothermal, ocean tidal waves, hydro, etc.

According to Rutansh and Bhargav, (2014), a large amount of energy is extracted, distributed, converted and consumed in the world on a daily basis, with $85 \%$ of the production dependent on the non-renewable and fossil sources [1]. To confirm this claim, the International Energy Agency (IEA) in 2014 estimated that the global energy demand will grow by $37 \%$ by the year 2040 and the supply mix will be divided into almost four equal parts between oil, gas, coal and the low carbon sources [2]. The world's dependence on fossil fuel is the reason for its high cost, air pollution, climatic change and other environmental disasters. Another problem associated with the use of conventional energy sources is that they are limited and in continuous depreciation of quantity with increase in the consumption rate. With the current consumption trend, they will finish within a few decades [3]. This leaves the world with an alternative; the renewable sources, which are clean, safe, reliable and can be easily accessed [4, 5]. 
Solar energy is the most used renewable energy source in the world. This is due to its availability in most parts of the world. It is also pollution free and flexible in installation. Besides, it is inexhaustible and most promising when compared with other renewable sources due to its advantage of having less or no maintenance requirement, high potential applications in remote areas and large quantity received per hour [6]. Nabin, (2012) reported that the amount of energy released by the sun in one hour $\left(4.30 \times 10^{22} \mathrm{~J}\right)$ was discovered to be more than the energy consumed in the whole world in $2001\left(4.10 \times 10^{22} \mathrm{~J}\right)$ [7]. Even with this high potential, low efficiency and high initial cost are the major challenge for the development of solar energy technologies [8].

Nigeria is a country with great potential in solar energy as it lies within the sunshine belt and receives global solar radiation varying from $3.5 \mathrm{kWh} /\left(\mathrm{m}^{2}\right.$.day) in the coastal areas to more than $7 \mathrm{kWh} /\left(\mathrm{m}^{2}\right.$.day $)$ in the far north, and an average sunshine hours per day of 4 to 9 hours that also ranges from the coastal areas to the northern part of the country [9]. Research has shown that if solar systems are installed to cover just $1 \%$ of the county's area, energy of $1.85 \times 10^{6} \mathrm{GWh}$ can be generated in a year. This is over a 100 times more than the country's power consumption on a yearly base [8].

The Photovoltaic (PV) solar system is the fastest growing renewable energy in Nigeria. More than $15 \mathrm{MW}$ of power is generated through it and dispersed in different places as standalone [8]. The millennium development goals (MDGs) program is a key contributor to the growth of PV installation especially in the rural areas. There are a few solar thermal systems like solar cookers, solar dryers, and solar incubators developed in the country, but most of them are for research purposes. There is no PV or solar thermal plant that is connected to the national grid. The slow development of the solar systems in Nigeria could be associated with a number of factors including; high cost with regards to initial capital investment, zero incentive, lack of awareness, inadequate research, etc. This made it impossible for the solar technology to meet the required input to the energy mix of $14 \%$ in 2008 and $23 \%$ in 2015 . And unless urgent steps in the right direction are taken, the projected mix of $36 \%$ in 2030 by the presidential committee on power development will not be achieved [9].

There are several applications of solar thermal systems in the world that makes use of parabolic trough collectors (PTCs). The largest of such systems are the Southern California power plants, Solar Electric Generating Systems (SEGS) plants with a total installed capacity of $354 \mathrm{MW}$, the 280 MW Solana Generating Station with molten salt heat storage in Arizona, the $250 \mathrm{MW}$ Genesis Solar Energy Project located in the Mojave Desert in California, the Spanish 200 MW Solaben Solar Power Station, and the 150 MW Andasol 1 solar power station, located near Guadix in Andalusia, Spain. However, these systems depend on fossil fuels or electricity to pump to pump the working fluids through the solar thermal system. This limitation has made the free-convective (thermosiphon) highly attractive [10].

The application of thermosiphon to solar water heating dates back to over a 100 years, but it is mostly applied to flat plate solar collectors. Morrison and Ranatunga carried out an experimental and theoretical analysis on the characteristics of thermosiphonic flow [11]. Several other researchers studied the thermal performance of the natural circulating heat pipe system [12-15] and reported that the results showed that solar heat pipe system has a good thermal performance. Studies have also been carried out on thermosiphon system design and optimization [16-20]. Their results revealed that solar water heating performs better with natural circulating heat pipe. Shah and Furbo reported that a U-tube receiver was successful in domestic solar hot water system, in that it was convenient to seal and performed better [21]. Shafahi et al., and Huminic et al., applied nanoparticles in free-circulation system and observed that thermal characteristics were enhanced [22, 23]. Zhang, et al., in their work, designed a Utype solar receiver, coupled it with a natural circulation heat pipe system and applied to a PTC system. The system generated medium-temperature $\left(120-200^{\circ} \mathrm{C}\right)$ steam with a pressure of up to $0.75 \mathrm{MPa}$. During summer, the efficiency of the system was found to be $38.52 \%$ at a discharging pressure of $0.5 \mathrm{MPa}$. Their suggested that an optimization on thermal insulation and collector exit design would increase the system's efficiency and reliability [24]. These works show that the generation of steam through free convective (or natural circulation) solar heat pipe have several advantages (simple to construct, widely adjustable, easier to control and high heat transfer ability even at low temperature differences etc.) when compared with forced circulation system. But there is scanty information on the application of natural (free) convection to parabolic trough collector (PTC), especially with linear receivers for solar water heating or steam generation. This is what this work seeks to achieve.

\section{Experimental Design}

The solar thermal system consists of a parabolic trough solar collector, a well-insulated vertical cylindrical vessel (tank), a copper heat collecting pipe, a flexible ascending pipe, a descending pipe and a digital flow meter shown in Figure 1. At the start of the experiment, cold water from the tank descended under gravity, through the descending pipe into the heat receiver, where it was heated to a higher temperature. The hot water, less dense and more buoyant than the cold water in the tank was moved by natural convection (thermosiphon) through the ascending pipe into the tank where it transferred heat to the water in the tank. The water from the tank then flowed back to the receiver by gravity through the descending pipe. The cycle continued as long as there was heat absorption, resulting into a potential gradient between the descending and ascending pipes to provide a driving force for natural circulation until the water attained boiling temperature. The high temperature and pressurized water was flashed into the tank, which also served as a steam separator at atmospheric pressure.

In order to minimize heat losses and enhance the efficiency of the system, the ascending and descending pipes were 
insulated. A pressure release valve and water level meter were installed on the vertical cylindrical flash vessel to ensure quality discharging steam and to monitor the water level respectively. The specifications of the solar collector system are presented in Table 1.

Seven (7) WZP PT100 Temperature Sensors [ $\left(T_{\text {rec. }}\right),\left(T_{\text {in }}\right)$,
$\left(\mathrm{T}_{\text {out }}\right),\left(\mathrm{T}_{\text {water }}\right),\left(\mathrm{T}_{\text {vapor }}\right),\left(\mathrm{T}_{\text {tank }}\right)$ and $\left.\left(\mathrm{T}_{\text {amb. }}\right)\right]$ were installed at different points in the system to investigate temperature distribution within the system. $\mathrm{T}_{\text {rec }}$ was installed on the heat receiver to measure variations in the temperature of the heat receiver. $T_{\text {in }}$ and $T_{\text {out }}$ were installed at the end of the descending pipe and beginning of ascending pipe

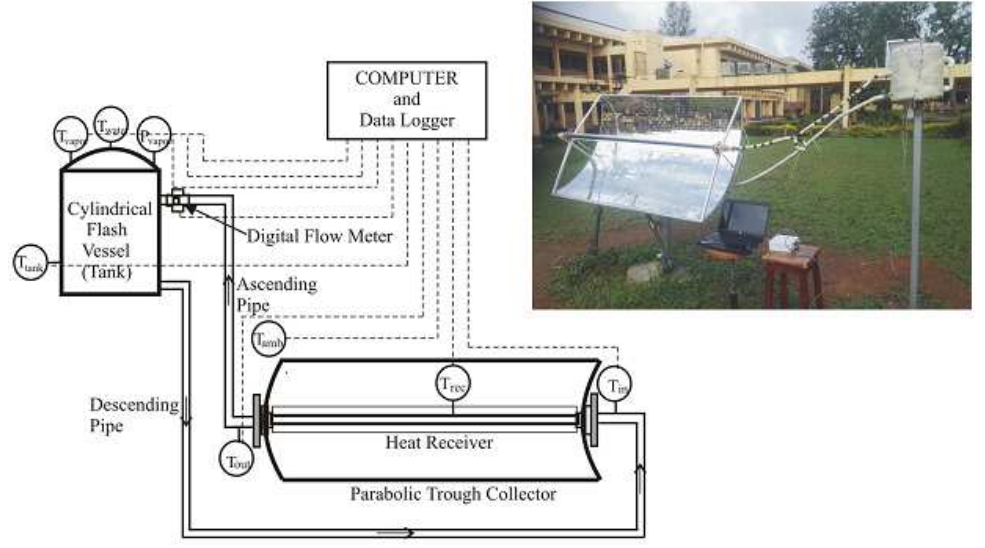

Figure 1. Schematic Diagram of Experimental Set up.

Table 1. Specifications of the Parabolic Trough Collector Steam Generating System.

\begin{tabular}{lll}
\hline & Item & Value/type \\
\hline & Collector aperture area & $1.50 \mathrm{~m}^{2}$ \\
& Collector aperture width & $1.00 \mathrm{~m}$ \\
& Receiver diameter & $25.4 \mathrm{~mm}$ \\
& Receiver length & $1.50 \mathrm{~m}$ \\
& Receiver's aperture area & 0.0381 \\
PTC & Receiver coating & Black \\
system & Glass tube & $55 \mathrm{~mm} / 65 \mathrm{~mm}$ \\
& Concentration ratio & 39.4 \\
& Rim angle & $78.68^{\circ}$ \\
& Working fluid & Water \\
& Tracking mechanism type & Electronic \\
& Mode of tracking collector axis & N-S horizontal, E-W \\
& tracking \\
Tank & Dimensions (External) & $30 \mathrm{~cm} \times 32 \mathrm{~cm}$ \\
& Dimensions (Internal) & $23.4 \times 28 \mathrm{~cm}$ \\
& Volume & $\sim 12.0 \mathrm{~L}$ \\
\hline
\end{tabular}

respectively, to measure the temperature of the water just before it enters the heat receiver and when it exits the receiver. $T_{\text {water }}$ and $T_{\text {vapor }}$ were installed inside the vertical cylindrical vessel with $T_{\text {water }}$ at the bottom (but not in contact with the wall of the tank) to measure the temperature of water in the tank and $\mathrm{T}_{\text {vapor }}$ at the top of the tank to measure the temperature of vapor (steam). $\mathrm{T}_{\text {tank }}$ was installed on the external wall of the tank to measure the external temperature. $\mathrm{T}_{\mathrm{amb}}$. was installed close to the PTC (but not in direct contact with any object, other than air) to measure the ambient temperature.

A SEA SMART Digital Flow Meter with an inbuilt Hydraulic Electromagnetic Flow Sensor YF-DN80 was installed at the end of the ascending pipe to measure the mass flow rate of water in the system. An Eyourlife Universal 500PSI pressure sensor $\left(\mathrm{P}_{\text {vapor }}\right)$ was also installed in the tank to measure the pressure. Apart from $\mathrm{T}_{\text {water }}$ and $\mathrm{T}_{\text {vapor }}$ that were istalled inside the tank, all the temperature sensors were placed on the surface of the pipes and tank and covered with an insulating material. The temperature sensors were of an accuracy of $\pm 0.15^{\circ} \mathrm{C}$. Global Solar Radiation in the experimental region was measured using a TENMARS, Model TM - 206 Solar Power Meter with an accuracy of \pm $10 \mathrm{~W} / \mathrm{m}^{2}$. The temperatures and pressure signals were gathered by an Arduino data acquisition board to a personal Computer.

The experiment was carried out on the $12^{\text {th }}$ and $15^{\text {th }}$ of May, 2019. This was at the beginning of the wet (rainy) season, which starts in April and ends in the month of October in the middle-belt region of Nigeria [25]. The experimental set-up was at the University of Ilorin permanent site.

\section{Results and Discussion}

\subsection{Thermal Characteristic of Thermosiphon Heat Pipe PTC System}

The average temperatures and pressure distributions of the thermosiphon heat pipe PTC system for the two days examined are presented as a function of the time of the day in Figure 2 ( $a$ and $b$ ). The graphs are categorized into four different stages: the starting $(\mathrm{a}-\mathrm{b})$ stage, the water heating ( $b$ - c) stage, the steam discharging (c - d) stage and the ending/cooling $(\mathrm{d}-\mathrm{e})$ stage.

At the starting $(\mathrm{a}-\mathrm{b})$ stage, the receiver (copper pipe) absorbs solar radiation reflected from the concentrator to converge on it, and a rise in its average temperature and with time that of the ascending pipe $\left(\mathrm{T}_{\text {out }}\right)$ as heat was transferred to the water in the pipe was observed. The temperatures of the other parts of the system were either stable or with little changes at the starting $(\mathrm{a}-\mathrm{b})$ stage. This was because circulation of water in the system had not started. 


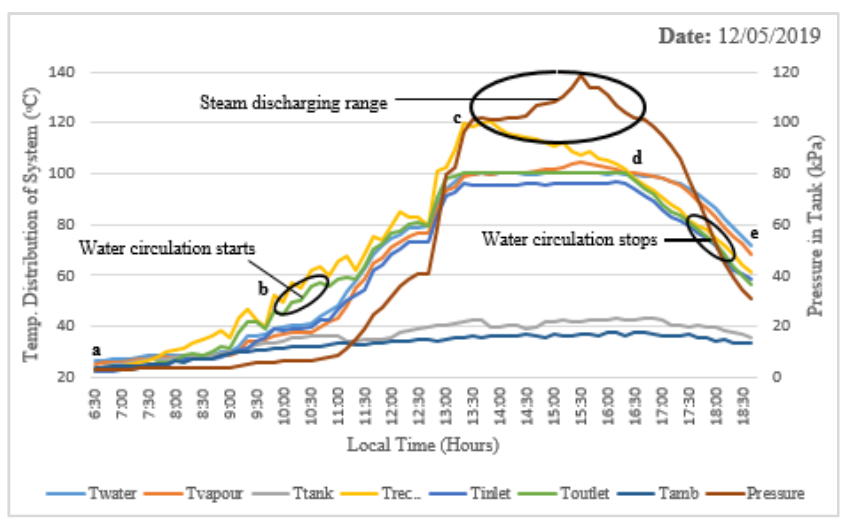

(a)

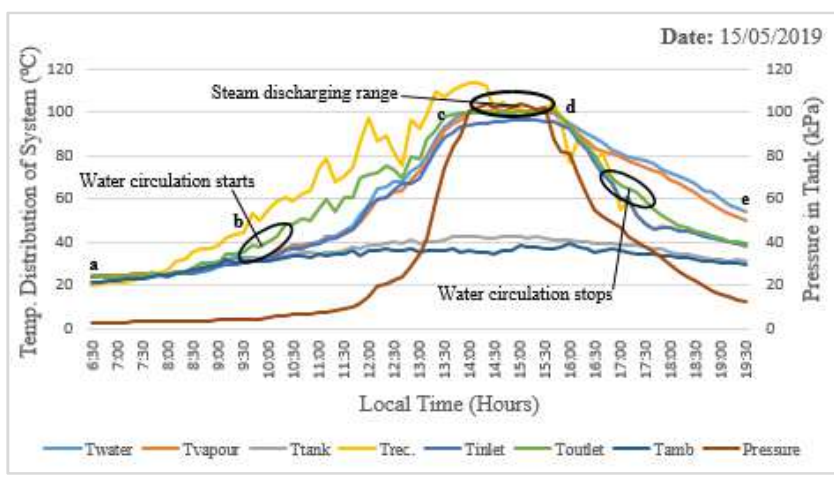

(b)

Figure 2. Temperature and Pressure Distributions of Thermosiphon Heat Pipe PTC System as a Function of Time of the Day on (a) 12/05/2019 and (b) $15 / 05 / 2019$.

The continuous rise in the temperatures of the receiver and the ascending pipes triggered circulation. This caused a mass movement of water from the receiver and subsequent heat transfer to the water in the tank. This is the water heating (bc) stage. At this stage, there is a gradual rise in the average temperatures of the water in the tank $\left(\mathrm{T}_{\text {water }}\right)$, the descending pipe $\left(T_{i n}\right)$ and vapor $\left(T_{\text {vapor }}\right)$, but the temperatures of the receiver $\left(\mathrm{T}_{\text {rec }}\right)$ and ascending pipe $\left(\mathrm{T}_{\text {out }}\right)$ remained higher until the water in the system attained boiling point. Slight changes in the average temperature of the external wall of the tank were also observed. This could be due to conduction and convectional heat transfer from the interior of the tank to its wall and convectional heat transfer from the environment to the wall of the tank. The pressure in the tank $\left(\mathrm{P}_{\text {vapor }}\right)$ was also raised gradually.

The average temperatures of the receiver $\left(\mathrm{T}_{\text {rec. }}\right)$ also varied directly with the solar radiation as shown in Figure $3(\mathrm{a}-\mathrm{b})$ as a strong correlation of 0.76 and 0.92 respectively was estimated for the $12^{\text {th }}$ and $15^{\text {th }}$ May, 2019. This agreed favorably with the results of Agbo and Unachukwu [20].

The steam discharging $(c-d)$ stage began when the water started boiling. It is important to point out at this stage that apart from the results in Figure 2 (a) where $T_{\text {vapor }}$ was above $100^{\circ} \mathrm{C}$ between $14: 30$ and $16: 00$ hours, resulting into a rise in pressure of up to $118.6 \mathrm{kPa}$, the pressure in the

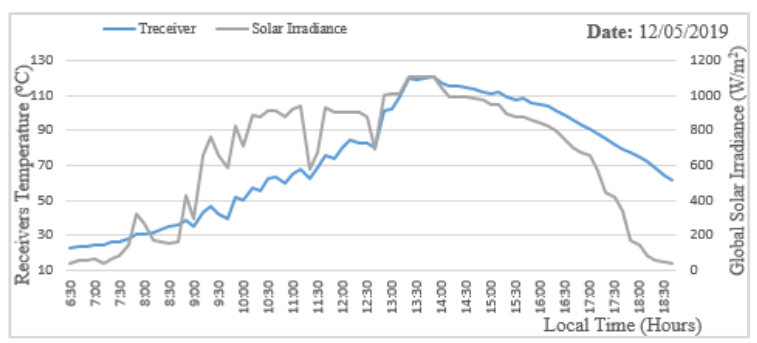

(a)

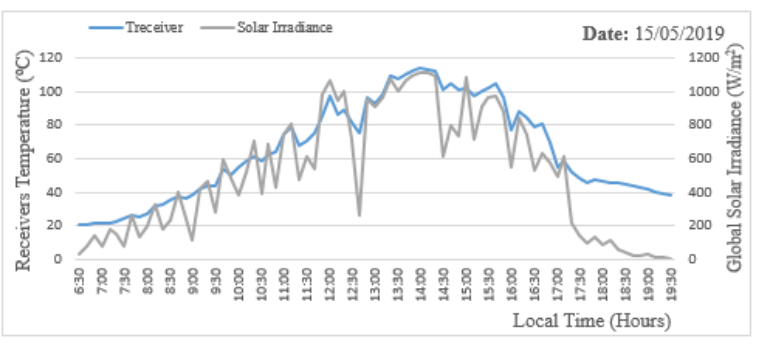

(b)

Figure 3. Variation of Receivers Temperature with Global Solar Irradiance for (a) $12 / 05 / 2019$ and (b) 15/05/2019.

tank and the average temperatures of the ascending pipe ( $\left.\mathrm{T}_{\text {out }}\right)$, descending pipe $\left(\mathrm{T}_{\text {in }}\right)$, water in the tank $\left(\mathrm{T}_{\text {water }}\right)$ and vapour temperature $\left(\mathrm{T}_{\text {vapor }}\right)$ were reasonably stable in Figure 2 ( $\mathrm{a}$ and $\mathrm{b}$ ). The rise in $\mathrm{T}_{\text {vapor }}$ of above $100^{\circ} \mathrm{C}$ was caused by a stiffness in the release valve, resulting into the production of superheated steam. It is also important to note that $T_{\text {water }}$ was greater than $\mathrm{T}_{\text {vapor }}$ at the starting and water heating stages, but $\mathrm{T}_{\text {vapor }}$ was either greater than or equal to $T_{\text {water }}$ at the steam discharging stage. This agrees with the observations of Mathioulakis and Belessiotis [17].

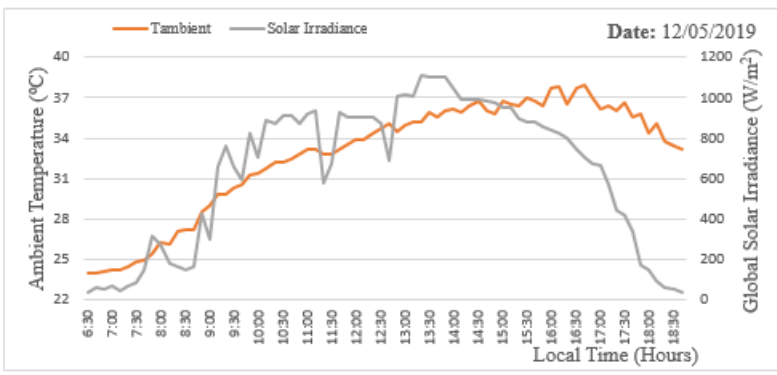

(a)

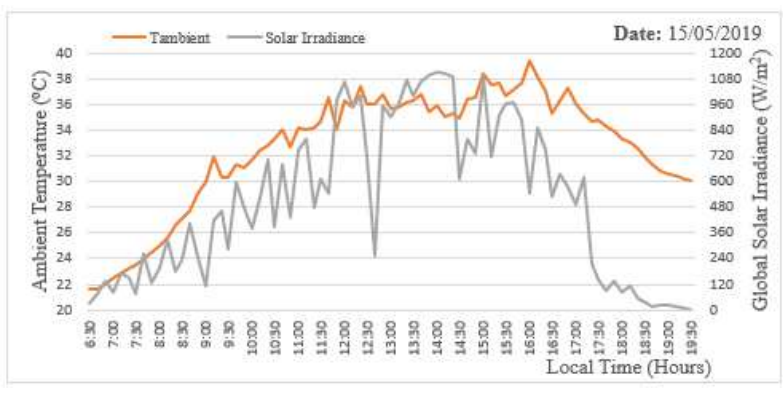

(b)

Figure 4. Variation of Ambient Temperatures with Global Solar Irradiance as a Function of Time of the Day for (a) 12/05/2019 and (b) 15/05/2019. 
As expected, a steady decline in the average temperatures of the system was observed in the ending/cooling $(d-e)$ stage as shown in Figure 2 ( $a$ and $b$ ) with $\mathrm{T}_{\text {water }}$ being the highest at close of work for the two days examined. It was also observed that thermosiphon flow stopped in the ending/cooling stage of the system. The temperatures at which flow stopped were all higher when compared with the temperatures at which it started. The results also showed that ambient temperature $\left(\mathrm{T}_{\mathrm{amb}}\right.$. $)$ varied between $23.94^{\circ} \mathrm{C}$ and $37.97^{\circ} \mathrm{C}, 21.12^{\circ} \mathrm{C}$ and $39.38^{\circ} \mathrm{C}$ for the $12^{\text {th }}$ and $15^{\text {th }}$ May, 2019 respectively. These variations were moderately dependent on the global solar radiation [see Figure $4(\mathrm{a}-\mathrm{b})$ ] as a correlation of 0.69 and 0.70 respectively for the $12^{\text {th }}$ and $15^{\text {th }} 2019$ was estimated. This means that solar radiation is not the only factor responsible for the ambient temperature.

The maximum water temperature and the receiver temperature were obtained between 13:00 hours and 16:00 hours (see Figure $2 \mathrm{a}-\mathrm{b}$ ). The global solar radiation increased from very low value at 6:30 hours got to the peak between noon and 14:00 hour and then decreased back to very low values.

\subsection{Thermal Efficiency of Thermosiphonic Heat Pipe PTC System}

The results in Figure $2(\mathrm{a}-\mathrm{b})$, shows that the thermosiphon heat pipe PTC system can generate low-mid temperature steam. The instantaneous efficiency of the receiver was calculated as a function of time of day by the use of equation 1 [26].

$$
\eta=\frac{m c\left(T_{\text {out }}-T_{\text {in }}\right)}{G_{t} A_{c}}
$$

Where $\eta, m, c, T_{\text {out }}, T_{i n}, G_{t}$ and $A_{c}$ are the instantaneous thermal efficiency, thermosiphon mass flow rate, specific heat capacity of water, outlet temperature, inlet temperature, global solar radiation and collector aperture area respectively. The results show that the efficiency of the system reached up to $46.48 \%$ on the $12^{\text {th }}$ of May, 2019 . This efficiency is higher than that of Zhang et al. who used a U-type natural circulation heat pipe system as receiver in a parabolic trough solar collector and generating mid-temperature steam with a thermal efficiency of $38.52 \%$ [24].

The instantaneous efficiency of the receiver for the two days examined showed a strong dependence on the thermosiphon mass flow rate as shown in Figure $5(a-b)$. The correlation between the thermal efficiency of the receiver and thermosiphon mass flow rate was determined to be 0.89 and 0.81 for the $12^{\text {th }}$ and $15^{\text {th }}$ May, 2019 respectively. The highest value for the thermal efficiency of $46.48 \%$ obtained on the $12^{\text {th }}$ of May, 2019 at 13:20 hours was recorded when the mass flow rate of the working fluid was also at its highest value of $0.042 \mathrm{~kg} / \mathrm{s}$. The same thing was observed on the $15^{\text {th }}$ of May, 2019 when the highest value for thermal efficiency of $43.1 \%$ was recorded at 14:00 hours when the mass flow

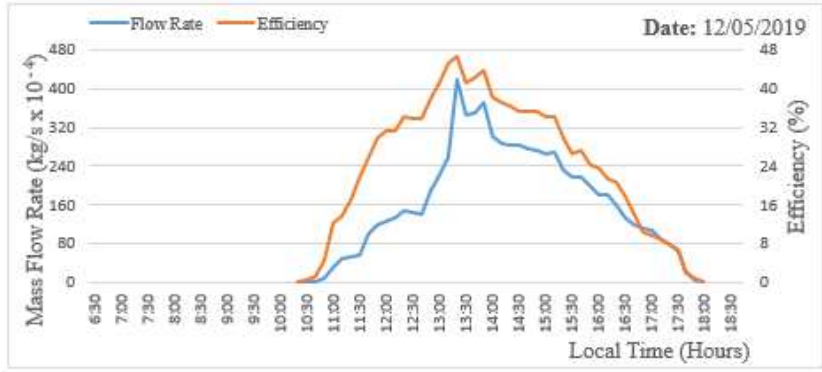

(a)

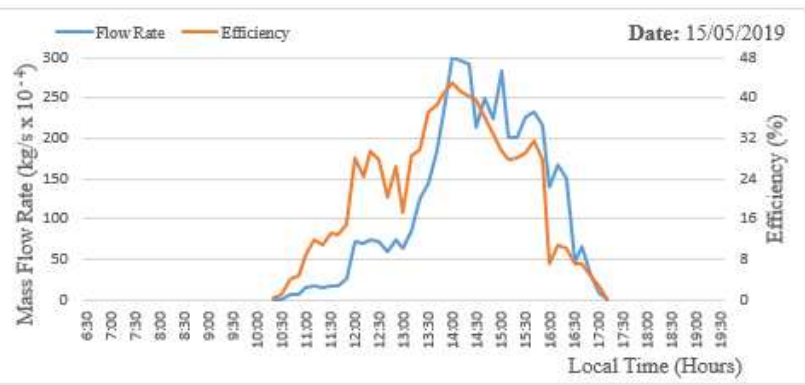

(b)

Figure 5. Mass Flow Rate Distribution and Efficiency as a Function of the Time of the Day for (a) 12/05/2019 and (b) 15/05/2019 rate was at its highest value of $0.03 \mathrm{~kg} / \mathrm{s}$.

The instantaneous efficiency of the receiver for the two days examined showed a moderate dependence on the global solar radiation as shown in Figure $6(\mathrm{a}-\mathrm{b})$. The linear correlation between the thermal efficiency of the receiver and the global solar radiation was determined to be 0.72 and 0.71 for the $12^{\text {th }}$ and $15^{\text {th }}$ May, 2019 respectively.

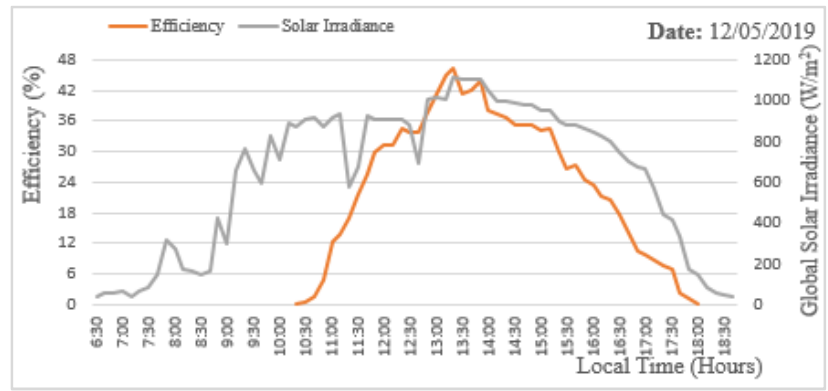

(a)

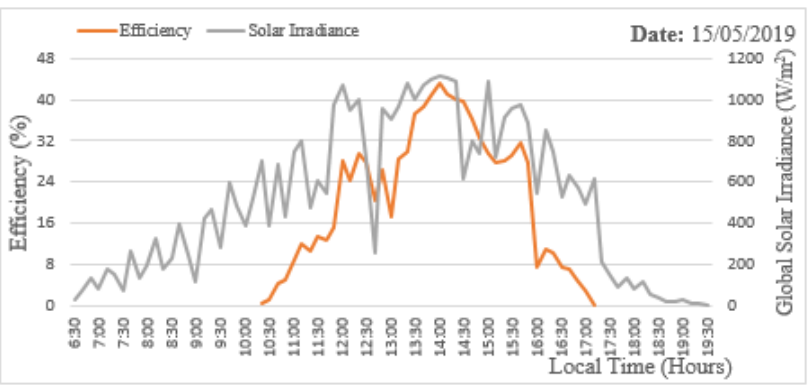

(b)

Figure 6. Efficiency and Global Solar Irradiance as a Function of Time of the Day for (a) 12/05/2019 and (b) 15/05/2019. 
The instantaneous efficiency of the receiver for the two days examined also showed a strong dependence on the receiver's temperature as presented in Figure $7(\mathrm{a}-\mathrm{b})$. The linear correlation between the thermal efficiency of the receiver and the receiver's temperature was determined to be 0.74 and 0.93 for the $12^{\text {th }}$ and $15^{\text {th }}$ May, 2019 respectively.

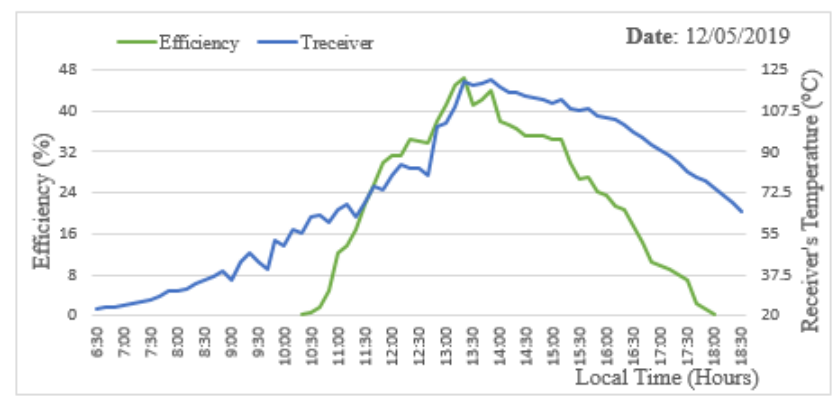

(a)

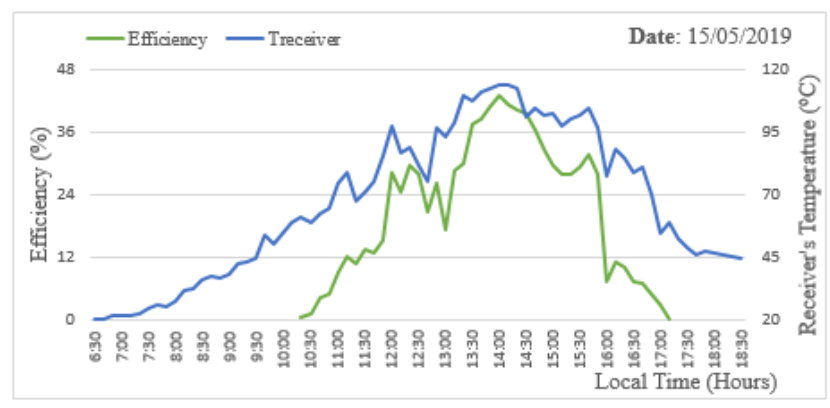

(b)

Figure 7. Variation of Instantaneous Efficiency of Receiver with Receiver's Temperature as a Function of Time of the Day for (a) 12/05/2019 and (b) $15 / 05 / 2019$

\section{Conclusion}

The surface of a parabolic trough collector (PTC) reflected and concentrated direct solar radiation to a heat collecting element (a copper tube enclosed in an evacuated glass shield) to heat up water in a solar thermal steam generating system. Thermosiphon technique was employed to drive through the working fluid (water) in a closed-loop from the heat source to the tank. Measurements of temperature distribution and pressure within the system were carried out with the use of temperature and pressure sensors respectively.

The results showed that the solar thermal system generated low-mid temperature steam of up to $105^{\circ} \mathrm{C}$ at a pressure of approximately $120 \mathrm{kPa}$ on a day when the global solar radiation intensity attained a value of $1109.5 \mathrm{~W} / \mathrm{m}^{2}$. The results also revealed a thermosiphon mass flow rate of up to $0.042 \mathrm{~kg} / \mathrm{s}$ through a constant orifice of $12 \mathrm{~mm}$ diameter. The instantaneous efficiency of the receiver reached $46.48 \%$

This result shows that, instead of using an electrical or mechanical power to pump a fluid through a closed-loop for solar water heating or generating steam, the natural circulating (thermosiphon) system with little or no degradation and maintenance cost can be applied to parabolic trough collector (PTC).

\section{References}

[1] Rutansh P. and Bhargav P. Solar Powered Stirling Engine- A New Hope, Global Journal of Research Analysis International, vol. 3, ISSN No. 2277 - 8160, 2014, p. 61-3.

[2] International Energy Agency, World Energy Outlook, 2014, OECD/ IEA: CORLET Paris cedex France.

[3] Sambo, A. S. Renewable Energy Technology for National Development: Status, Prospects and Policy Directions. in Annual General Meeting of the Nigerian Society of Engineers. Bauchi 2001: Nigeria Society of Engineers.

[4] Sims, R. E. H. Renewable energy: a response to climate change. Solar Energy, 76 (1-3): 2004, p. 9-17.

[5] Schimmelpfenning, D. The option value of renewable energy: the case of climate change. Energy Economics, 17 (4): 1995 p. 311-317.

[6] Lewis, N. S., Nocera, D. G. Powering the planet: Chemical challenges in Solar Energy Utilization. in National Academy of Sciences, 2006.

[7] Nabin, S. Design and Performance evaluation of a low concentrating Line - axis Dielectric Photovoltaic System, in School of Engineering and Physical Sciences, Heriot - Watt University, 2012.

[8] Sambo, A. S., Bala, E. J. Penetration of Solar Photovoltaic into Nigeria's Energy supply mix. in World Renewable Energy Forum (WREF). Denver, Colorado USA: Curran Association Inc. 2012

[9] Sambo, A. S. Matching Electricity Supply with Demand in Nigeria, Energy Commission of Nigeria (ECN). 2008, p. 17 21.

[10] Norton, B., Probert, S. D. Natural circulation solar energy simulated systems for heating water. Applied Energy 11, 1982, 167-196.

[11] Morrison and Ranatunga, Thermosiphon circulation in solar collectors. Journal of Solar Energy, 24, 1980, p. 191-198.

[12] Ismail, K. A. R., Abogderah, M. M. Performance of heat pipe solar collector. Journal of Solar Energy Engineering 120, 1998, p. 51-59.

[13] Yu, Z. T., Hu, Y. C., Hong, R. H., Cen, K. F. Investigation and analysis on a cellular heat pipe flat solar heater. Heat and Mass Transfer 42, 2005, 122-128.

[14] Rittidech, S., Wannapakne, S. Experimental study of the performance of a solar collector by closed-end oscillating heat pipe (CEOHP). Applied Thermal Engineering 27, 2007, p. 1978-1985.

[15] Azad, E., Theoretical and experimental investigation of heat pipe solar collector. Experimental Thermal and Fluid Science 32, 2008, p. 1666-1672.

[16] Hussein, H. M. S., Mohamad, M. A., Belessiotis, V., Optimization of a wickless heat pipe flat plate solar collector. Energy Conversion \& Management 40, 1999, p. 1949-1961.

[17] Mathioulakis, E., Belessiotis, V. A new heat-pipe solar domestic hot water system. Solar Energy 72, 2002, p. 13-20. 
[18] Tanaka, H., Nakatake, Y. A vertical multiple-effect diffusiontype solar still coupled with a heat pipe solar collector. Desalination 160, 2004, p. 195-205.

[19] Hobbi, A., Siddiqui, K. Experimental study on the effect of heat transfer enhancement devices in flat-plate solar collectors. International Journal of Heat and Mass transfer 52, 2009 , p. $4650-4658$.

[20] Agbo, S. N. and Unachukwu, G. O. Design and Performance Features of a Domestic Thermosiphon Solar Water Heater for an Averaged-Sized Family in Nsukka Urban, Trends in Applied Sciences Research 2 (3): p. 224-230, 2007 ISSN 1819-3579.

[21] Shah, L. J., Furbo, S. Theoretical flow investigations of an all glass evacuated tubular collector. Solar Energy 81, 2007, p. $822-828$.

[22] Shafahi, M., Bianco, V., Vafai, K., Manca, O. Thermal performance of flat-shaped heat pipes using nanofluids. International Journal of Heat and Mass Transfer 53, 2010, p. $1438-1445$.
[23] Huminic, G., Huminic, A., Morjan, I., Dumitrche, F. Experimental study of the thermal performance of thermosyphon heat pipe using iron oxide nanoparticles. International Journal of Heat and Mass Transfer 54, 2011, p. 656-661.

[24] Zhang L, Wang WJ, Yu ZT, Fan LW, Hu YC, Ni Y, Fan Jianren, Cen Kefa (2012). An experimental investigation of a natural circulation heat pipe system applied to a parabolic trough solar collector steam generation system. Solar Energy 2012; 86: 911-9.

[25] Adedoyin, J. A. "Initiation of West African squall lines", Meteorology and Atmospheric Physics. 41: 1989, p. 99-103. doi: 10.1007/BF01043455.

[26] Zhang Liang, Yu Zitao, Fan Liwu, Wang Wujun, Chen Huan, $\mathrm{Hu}$ Yacai, Fan Jianren, Ni Mingjiang, Cen Kefa. An experimental investigation of the heat losses of a U-type solar heat pipe receiver of a parabolic trough collector-based natural circulation steam generation system, Renewable Energy 57 (2013) 262-8 